\title{
Motivation of University Students Towards the Use of Information and Communication Technologies and Their Relation to Learning Styles
}

\author{
https://doi.org/10.3991/ijet.v15i15.14347 \\ Oscar Navarro $\left.{ }^{(}\right)$, Francisco Javier Sanchez-Verdejo \\ Universidad de Castilla-La Mancha, Ciudad Real, Spain \\ Oscar. Navarro@uclm.es \\ Juana Maria Anguita \\ Universidad Rey Juan Carlos, Madrid, Spain \\ Angel Luis Gonzalez \\ Universidad de Castilla-La Mancha, Ciudad Real, Spain
}

\begin{abstract}
Motivation can influence the success of the teaching-learning process. The use of Information and Communication Technology (ICT) in Education is becoming more and more frequent. In fact, its presence is very engaging and may improve learning. This study is aimed at analysing the relation between university students' intrinsic motivation and their learning styles, where variables such as gender and the universities at which they study can be essential. For that purpose, the answers provided in both the IMI (Intrinsic Motivation Inventory) questionnaire and the Felder and Silverman's Learning Style Inventory by a sample of 272 students from two different universities have been taken into account. The two questionnaires were completed online, allowing access from any device with an internet connection. Once the data obtained was analysed, a high correlation among the six dimensions of the motivation questionnaire was observed. Said correlation does not apply to Felder and Silverman's test, where there is little correspondence among the eight styles in the inventory. A clear relation between two learning styles (Visual and Reflective) and intrinsic motivation is also noted. It should be highlighted that on examination of the variables corresponding to the university where student study and the latter's gender were examined, certain differences appeared, such as the prevalence of some learning styles in male participants.
\end{abstract}

Keywords-Motivation, learning style; intrinsic motivation inventory, Felder and Silverman's Test, ICT, University.

\section{Introduction}

Motivation is a resource that teachers have traditionally used as a natural source of learning and to achieve the objectives set out on the basis of students' needs. In the field 
of education, the ultimate goal of motivation is the performance of certain activities because of the inherent satisfaction they produce in the student and not because of the consequence or the product of the performance. The participant is encouraged to act in a playful manner or for a personal challenge rather than due to external rewards or pressures [1]. Depending on the fulfilment of basic psychological needs, intrinsic motivation can increase and have an active influence on the performance of any activity, having a great impact in the field of education [2].

From students' point of view, there are two types of motivation: extrinsic and intrinsic. At first, there may be a series of external aspects that positively affect students and favour an improvement in the teaching-learning process [3]. However, when the goals that relate to motivation are identified with learning, they imply interest on the part of the individual to develop and improve his/her ability. That is when you can talk about intrinsic motivation [4]. Therefore, it is clear that learning goals are different from performance or performance goals [5].

Vázquez and Manassero [6] delve into different aspects of motivation (such as the evolution of the concept, the instruments that can measure it or how to evaluate its dimensions) and highlight the need to understand the nature of motivation.

The concept of learning can be approached from different points of view and, as of today, there is no unanimity regarding its meaning. Initially, it was related to data expectations and competencies [7]. According to the theory of Social-Cognitive Learning, motivation influences the concept of self-efficacy that individuals have of themselves [8]. Nowadays, causal attribution theories, for which the environment and personality condition behavioural goals [9], are particularly important, given that students currently communicate and express themselves through Information and Communication Technologies (ICT). Digital natives feel the need to have these media as part of the methodologies and access to knowledge in order to feel motivated [10]. Hence, the use of different devices, such as a personal computer, a tablet and even a mobile phone, can be identified as an intrinsic motivational factor towards learning [4]. This can favour the acquisition of digital skills, so the incorporation of certain computer applications in the classroom will favour the entire teaching-learning process [11], as well as the application of strategies such as learning by discovery with the use of the Internet or through games [12].

This paper aims to analyse the motivation towards the use of Information and Communication Technologies in university education processes. This motivation may be related to the way in which student access knowledge. Therefore, we will try to determine the correspondence that exists between intrinsic motivation, the use of technologies and learning styles.

\section{Theoretical Framework}

In order to understand the work that has been carried out, it is necessary to conduct a brief review of the different concepts and tools that have been used. The IMI Questionnaire (Intrinsic Motivation Inventory) [13] and the Inventory of learning styles 
of Felder and Silverman [14] are also explained, including a description of their contents and main characteristics.

\subsection{Intrinsic Motivation}

Motivation is a feeling or personal state of diverse origin. It has a subjective character and is directly related to a person's degree of motivation and his / her desire to be motivated [15]. The mechanistic paradigm was in force during the first half of the last century. Its description of motivation considered variables such as impulse, instinct and activation $[16,17]$.

This conception changed as the cognitive paradigm emerged, which states that rewards can condition different motivations. In turn, it provides the motivational perspective of achievement and considers that said motivation is aimed at achieving goals. Atkinson (1976) [7] was the first to talk about this concept, although other authors, such as Heider (1958) [18] and later Jones and Davis (1965) [19], Kelley (1967) [20] and Weiner (1985) [21], also made their contributions in this regard. Their contributions served to lay the foundations for different theories that perceive motivation as a relation between expectations and the expected result.

The need or belief of need arises from an individual's wishes. This statement led Maslow [22] to develop the Motivation Theory, which established a hierarchy of the needs of human beings in order of ascending importance, starting from the most basic up to the highest level. The Theory of Need for Achievement [23] stemmed from this approach. Based on this theory, motivation is determined by three types of needs that are learned: need for power, need for achievement and need for affiliation. However, neither of these two authors considers other elements, such as the maturity or needs of the individual.

Later authors delved into the theory of motivation-related self-determination $[13,24,25,2]$. On the basis of their work, three components are established when studying motivation: affective-emotional reactions, beliefs about the benefits of a specific task and personally perceived competence to get involved in the task [26].

Motivation can encourage individuals to persist with a certain activity. Depending on the implication, it can be extrinsic or intrinsic motivation [2]. Intrinsic motivation refers to the trend towards searching for news and challenges. On the other hand, extrinsic motivation aims to achieve a certain result for reasons other than an inherent satisfaction of the activity. Regarding these two types of motivation, Grant and Dweck [27] affirm that the achievement of certain goals positively influences an individual's intrinsic motivation and performance, especially when faced with prolonged challenges. Likewise, McInerney, Marsh and Yeung [28] affirm that setting goals previously contributes to motivation being intrinsic and directing efforts towards achieving the desired results. In the field of education, teachers should always try to make motivation inherent in students in order to achieve a favourable development of the teaching and learning process.

Since one of the objectives of this work focuses on the study of intrinsic motivation in university students, Ryan and Deci's Intrinsic Motivation Inventory (IMI) has been used for analysis purposes. The IMI is a multidimensional measuring instrument that 
values participants' subjective experience in relation to a specific activity; in this case, the predisposition of university students to use Information and Communication Technologies. The IMI questionnaire consists of six subscales. One of these subscales, Interest/Enjoyment, is considered an intrinsic motivation measure per se, and is often taken into account more than others. Perceived Choice and Perceived Competence are two positive predictors of self-report and are measures of intrinsic motivational behaviour. Effort / Importance is an independent variable relevant to some motivational questions, so its use is considered relevant. Pressure/Tension is a negative predictor of motivation, indicating that an individual's results should be reversed. Finally, the Value/Usefulness subscale assesses internalization and self-regulation regarding the activity that students consider valuable and useful for themselves [29].

This tool has been used in various research studies with students of different ages $[30,31,32]$ and with teachers, just like this research study [33,34].

\subsection{Learning Styles}

Traditionally, it has been considered that all students learn in the same way. However, this homogenization of the educational process has been questioned by different theories, among which the Theory of Multiple Intelligences [35] stands out with the premise there can be different styles that personalize the abilities and qualities of each student. Learning style is conceived as the description of some behaviours and attitudes that determine the preferred mode of learning [36]. Keefe (1987) [37] considers that the psychological, affective and cognitive characteristics of behaviour serve as stable indicators of how students perceive, respond and interact with the learning environment. There are many tests that allow you to know the different learning styles. Some of the best known are the Honey and Mumford model (1986) [38], the Rose model (1985) [39], the HBDI model (Hermann Brain Dominance) (1996) [40], the Gardner model (1983) [41], the Kolb model (1976) [42] and the CHAEA Questionnaire by Honey-Alonso [43]. Possibly, the last of those mentioned is the most widespread in Spanish language [44].

However, in the research carried out in this study, we have opted for the Felder and Silverman Learning Styles Inventory (The Index of Learning Styles, ILS) [14]. It is one of the most widespread models, consisting of forty-four items (just over half of Honey-Alonso's model). The Felder and Silverman model, which was applied for the first time at the University of North Carolina, classifies participants in four bipolar dimensions, which consist of two categories respectively. This way, it is possible to understand the manner in which information is accessed and handled [45,46].

According to the information that the individual prefers, a predisposition towards a Sensitive or Intuitive style can be shown. People who show preference for a sensitive mode request an explanation, even if brief, after the examples. On the other hand, intuitive people primarily choose the establishment of relations and the discovery of different possibilities. Sensory individuals may perceive certain details or facts better, while intuitive individuals work faster and prefer to do the learning themselves. Regarding the presence of verbal language when the information is displayed, the Visual and Verbal dichotomy arises. For persons with a visual profile, it is easier to 
perceive the world around them and recreate it. In addition, they prefer receiving information visually through images, movies, graphics, etc. On the other hand, when the verbal option predominates, there is a greater preference for a style with explanations, whether oral or written. A reflective or active learning style can also be presented depending on students' attitude when processing the information. People with an active style apply their knowledge in the environment, in the real context. On the other hand, a reflective attitude allows access to information in a cognitive manner, favouring reasoning. Finally, depending on the organization and structuring of information when thinking is constructed, it is possible to opt for a Sequential or Global mode. People with a sequential learning style have a preference for accessing to information in a systematic way and in a logical order. Those who learn globally have a more general vision and can solve problems more quickly, but without having a clear knowledge of the process [47].

\section{Methods}

This study aims, first of all, to show the degree of motivation that university students pursuing a Master's Degree have towards the use of Information and Communication Technologies, and to contrast the data obtained with each participant's learning styles and check the relation between the two. With regard to the specific objectives, the following are proposed:

- Know the intrinsic motivation of future teachers about the use of ICTs in their teaching work

- Find out the learning style of future teachers

- Check the correlation between intrinsic motivation towards the use of ICTs and learning styles

- Confirm if there are differences in intrinsic motivation towards the use of ICTs according to participants' gender

- Check the differences in intrinsic motivation towards the use of ICTs according to participants' home university

For this purpose, the data of a sampling of students enrolled in the Master's Program defined in different contexts has been taken into account. On one hand, 128 participants study at the Universidad de Castilla-La Mancha (Spain) and, on the other, 144 study at the Universidad Rey Juan Carlos (Spain). In the sample, 70 are male and 202 females. In the Master's Degree studies, there is a greater predominance of women. The participants had to fill out two questionnaires prepared with the Google Forms tool. These questionnaires comprised a total of 81 questions ( 37 in the IMI questionnaire and 44 in the Felder and Silverman Inventory), which were intended to distinguish the degree of motivation towards the students' future work as teachers and the predominant learning style in the manner of accessing knowledge according to their personal characteristics. Both questionnaires could be completed through the Internet with a personal computer, a tablet or even a mobile, which facilitated and favoured students' participation. 


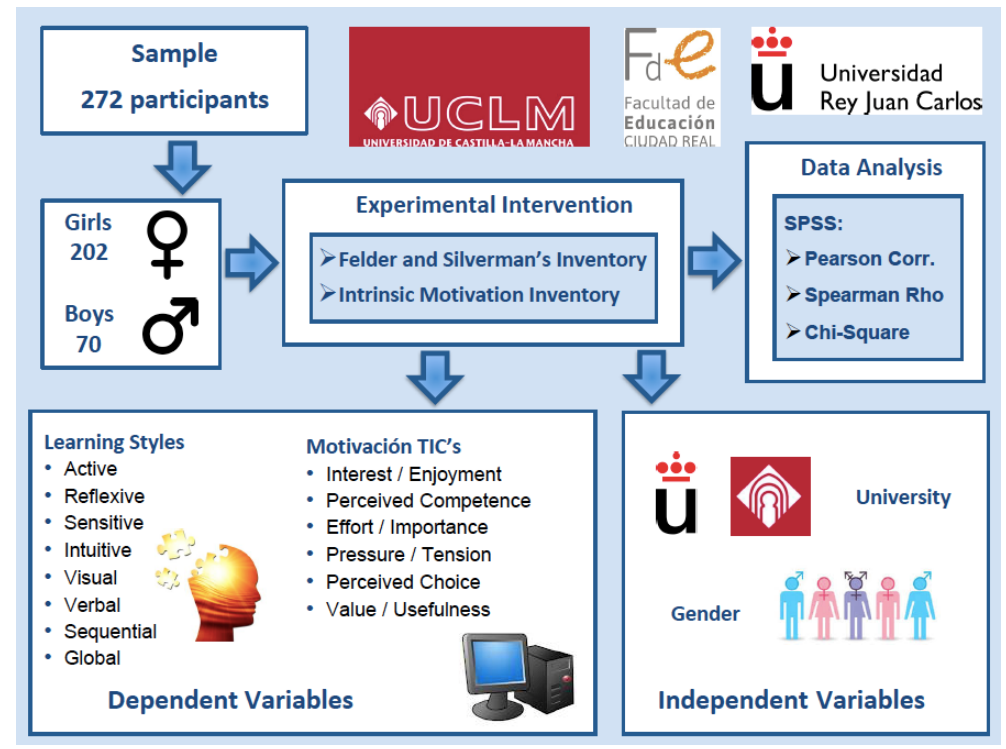

Fig. 1. Experimental Design

The independent variables were gender and the university at which the students were enrolled in the Master's Degree Program. Regarding the dependent variables, the six dimensions of the IMI questionnaire (Interest-Enjoyment, Perceived Competence, Effort-Importance, Pressure-Tension, Perceived Choice and Value-Usefulness) are considered [13]. Likewise, the student's learning style is taken into account as a dependent variable. In this case, mention is made of the eight styles that differentiate Felder and Silverman's Inventory of Learning Styles (Active, Reflective, Sensitive, Intuitive, Visual, Verbal, Sequential and Global) [14].

Based on the questionnaires and taking into account the variables mentioned, the following hypotheses were established:

- H1: There is a correlation among the subscales of the IMI questionnaire.

- $\mathbf{H}_{2}$ : There is a correlation among the participants' learning styles.

- H3: There is no a correlation among the subscales of the IMI questionnaire and learning styles.

- $\mathbf{H}_{4}$ : There are differences in intrinsic motivation for the use of participants' ICTs according to gender.

- H5: There are differences in participants' intrinsic motivation for the use of the ICTs according to the home university.

- H6: There are differences in the participants' learning styles according to gender.

- H7: There are differences in the participants' learning styles depending on the home university.

The results of the two questionnaires administered were exported to the Statistical Package for the Social Sciences (SPSS) software with the intention of processing the 
data. In order to analyse whether there is any correspondence among the different variables, the Pearson or Spearman correlation was used, depending on whether the variables are scalar or ordinal. The Chi-square test was also performed in order to assess whether there are significant differences in terms of gender or in terms of the university at which students' study. Finally, note is made that the contrast of means through Student's $t$ was used to check if there is a significant difference among the mean values obtained in the data collection.

\section{Results}

Based on the answers provided by the students participating in this research study, the relation or dependence among the different selected variables was analysed. First, the correlations among the six dimensions of intrinsic motivation are presented; then, the correlations among the eight selected learning styles; and, finally, a comparison is made between both types of correlation.

Table 1. Correlation (Pearson) among the dimensions of intrinsic motivation

\begin{tabular}{|c|c|c|c|c|c|c|}
\hline & $\begin{array}{c}\text { Interest / En- } \\
\text { joyment }\end{array}$ & $\begin{array}{c}\text { Perceived } \\
\text { Competence }\end{array}$ & $\begin{array}{c}\text { Effort / Im- } \\
\text { portance }\end{array}$ & $\begin{array}{c}\text { Pressure / } \\
\text { Tension }\end{array}$ & $\begin{array}{c}\text { Perceived } \\
\text { Choice }\end{array}$ & $\begin{array}{c}\text { Value / Use- } \\
\text { fulness }\end{array}$ \\
\hline \multirow{2}{*}{$\begin{array}{l}\text { Interest / En- } \\
\text { joyment }\end{array}$} & 1 & $0.665 * *$ & $0.601 * * *$ & $-0.350 * *$ & $0.204 *$ & $0.676 * *$ \\
\hline & . & 0.000 & 0.000 & 0.000 & 0.017 & 0.000 \\
\hline \multirow{2}{*}{$\begin{array}{l}\text { Perceived } \\
\text { Competence }\end{array}$} & & 1 & $0.569 * *$ & $-0.553 * *$ & $0.338 * *$ & $0.570 * *$ \\
\hline & & . & 0.000 & 0.000 & 0.000 & 0.000 \\
\hline \multirow{2}{*}{$\begin{array}{l}\text { Effort / Im- } \\
\text { portance }\end{array}$} & & & 1 & $-0.380 * *$ & 0.054 & $0.454 * *$ \\
\hline & & & . & 0.000 & 0.534 & 0.000 \\
\hline \multirow{2}{*}{$\begin{array}{l}\text { Pressure / Ten- } \\
\text { sion }\end{array}$} & & & & 1 & 0.107 & $-0.181 *$ \\
\hline & & & & . & 0.215 & 0.035 \\
\hline \multirow{2}{*}{$\begin{array}{l}\text { Perceived } \\
\text { Choice }\end{array}$} & & & & & 1 & $0.323 * *$ \\
\hline & & & & & . & 0.000 \\
\hline \multirow{2}{*}{$\begin{array}{l}\text { Value / Useful- } \\
\text { ness }\end{array}$} & & & & & & 1 \\
\hline & & & & & & . \\
\hline
\end{tabular}

** Correlation is significant at the level 0.01 (bilateral).

* Correlation is significant at the level 0.05 (bilateral).

Table 1 shows that there is a high correlation among almost all variables, with the exception of Perceived Choice in relation to Effort/Importance, on the one hand, and Pressure/Tension, on the other. In addition, the correlation coefficient is significant at the 0.01 level in almost all cases, which indicates that the correlation in question is very strong. Furthermore, as expected, the variable Pressure/Tension always has negative values, implying that a high value in this dimension corresponds to low values in all others. As these are quantitative variables, Pearson's correlation was. 
Table 2. Correlation (Spearman) among the learning styles

\begin{tabular}{|c|c|c|c|c|c|c|c|c|}
\hline & Active & Reflexive & Sensitive & Intuitive & Visual & Verbal & Sequential & Global \\
\hline \multirow{2}{*}{ Active } & 1 & -0.115 & -0.117 & 0.047 & 0.008 & -0.154 & 0.026 & -0.142 \\
\hline & . & 0.183 & 0.175 & 0.585 & 0.926 & 0.074 & 0.760 & 0.100 \\
\hline \multirow{2}{*}{ Reflexive } & & 1 & $-0.169^{*}$ & $\mathrm{0.386}^{* * *}$ & 0.031 & -0.041 & -0.119 & -0.037 \\
\hline & & $\cdot$ & 0.049 & 0.000 & 0.718 & 0.639 & 0.169 & 0.666 \\
\hline \multirow{2}{*}{ Sensitive } & & & 1 & $-0.209^{*}$ & $0.255^{* *}$ & -0.123 & 0.022 & 0.011 \\
\hline & & & . & 0.015 & 0.003 & 0.154 & 0.798 & 0.902 \\
\hline \multirow{2}{*}{ Intuitive } & & & & 1 & -0.044 & -0.050 & $0.177^{*}$ & -0.046 \\
\hline & & & & . & 0.615 & 0.563 & 0.039 & 0.594 \\
\hline \multirow{2}{*}{ Visual } & & & & & 1 & $-0.225^{* *}$ & $-0.187^{*}$ & -0.046 \\
\hline & & & & & . & 0.008 & 0.029 & 0.595 \\
\hline \multirow{2}{*}{ Verbal } & & & & & & 1 & -0.031 & -0.050 \\
\hline & & & & & & . & 0.721 & 0.563 \\
\hline \multirow{2}{*}{ Sequential } & & & & & & & 1 & -0.146 \\
\hline & & & & & & & . & 0.089 \\
\hline \multirow{2}{*}{ Global } & & & & & & & & 1 \\
\hline & & & & & & & & \\
\hline
\end{tabular}

** Correlation is significant at the level 0.01 (bilateral).

* Correlation is significant at the level 0.05 (bilateral).

With regard to learning styles, a relation can only be seen in a small number of cases. Table 2 uses Spearman's correlation coefficient, a common statistic to analyse ordinal variables. Some results are predictable, such as the negative correlation between the Visual and Verbal learning styles, since these are two antagonistic variables. It should be noted that the level of significance is very high $-0.225(\mathrm{p}=0.008)$, below 0.01 . As in the previous case, there is an expected value, namely the negative value between the Sensitive and Intuitive learning styles, where Spearman's Rho values of -0.209 $(p=0.015)$ have been found. In this case, the level of significance is lower than in the previous one, whose value was 0.05 . The same occurs in the other two cases of negative correlation. The Visual learning style is also opposed to the Sequential style, with values of $-0.187(\mathrm{p}=0.029)$, and the Reflective and Sensitive styles with values of $-0.169(p=0.049)$. For all these cases, a high value in one of the variables implies a low value in the other. Thus, the presence of a Visual learning style in students implies the absence of Verbal and Sequential styles.

There are three cases in which the correlation is positive: when the values are high or low in one specific variable, they are also high in another. Thus, when the student's learning style is Reflective, it is also Intuitive. This correspondence has a value of 0.386 $(\mathrm{p}<0.001)$, with a very high level of significance, less than 0.01 . As before, a correlation is obtained with a high level of significance $(<0.01)$ between the Visual and Sensitive learning styles, with a value of $0.255(\mathrm{p}=0.003)$. Finally, there is also a positive correspondence between Sequential and Intuitive learning styles, with a value of $0.177(\mathrm{p}=0.039)$, although in this case the significance level is only 0.05 . 
Table 3. Correlation among intrinsic motivation dimensions and the learning styles

\begin{tabular}{|c|c|c|c|c|c|c|c|c|}
\hline & Active & \begin{tabular}{|l|} 
Reflexive \\
\end{tabular} & Sensitive & Intuitive & Visual & Verbal & Sequential & Global \\
\hline \multirow{2}{*}{$\begin{array}{l}\text { Interest / En- } \\
\text { joyment }\end{array}$} & -0.005 & $0.211^{*}$ & -0.012 & 0.104 & $\mathrm{0.435}^{* * *}$ & $-0.221^{* * *}$ & -0.023 & 0.044 \\
\hline & 0.954 & .014 & 0.887 & 0.227 & 0.000 & 0.010 & 0.794 & 0.608 \\
\hline \multirow{2}{*}{$\begin{array}{l}\text { Perceived } \\
\text { Competence }\end{array}$} & 0.016 & $200^{*}$ & -0.038 & 0.106 & $\mathrm{0.423}^{\text {*** }}$ & -0.156 & -0.122 & -0.139 \\
\hline & 0.857 & 020 & 7 & 19 & , & & 57 & 0.107 \\
\hline \multirow{2}{*}{$\begin{array}{l}\text { Effort / Im- } \\
\text { portance }\end{array}$} & 0.045 & 0.198* $^{*}$ & -0.009 & 0.072 & $\mathbf{0 . 3 5 5}^{* * *}$ & -0.057 & -0.077 & $-0.202^{*}$ \\
\hline & 0.607 & 0021 & 0.913 & 0.408 & 0.000 & 0.509 & 0.371 & 0.018 \\
\hline \multirow{2}{*}{$\begin{array}{l}\text { Pressure / } \\
\text { Tension }\end{array}$} & -0.021 & $-0.200^{*}$ & -0.012 & 0.099 & $-0.269^{* * *}$ & 38 & & 0.087 \\
\hline & 0.809 & 0.019 & 0.894 & 0.252 & 0.002 & 0.658 & 0.625 & 0.316 \\
\hline \multirow{2}{*}{\begin{tabular}{|l|} 
Perceived \\
Choice
\end{tabular}} & 0.080 & 53 & 18 & 02 & & 26 & 19 & -0.057 \\
\hline & 0.355 & 0.074 & 0.839 & 0.235 & & 0.761 & 0.573 & 0.513 \\
\hline \multirow{2}{*}{$\begin{array}{l}\text { Value / Use- } \\
\text { fulness }\end{array}$} & 0.134 & 0.029 & 0.060 & 0.095 & $0.287^{* *}$ & -0.153 & -0.039 & 0.040 \\
\hline & 0.120 & 0.739 & 0.491 & 0.271 & 0.001 & 0.076 & 0.651 & 0.643 \\
\hline
\end{tabular}

** Correlation is significant at the level 0.01 (bilateral).

* Correlation is significant at the level 0.05 (bilateral).

Table 3 shows the relation between intrinsic motivation towards the use of ICT and student learning styles. There is no clear correlation with the dimensions of the IMI questionnaire used. However, two of the styles considered show a clear correspondence with motivation.

The first of these is the Reflective learning style, which correlates with four of the dimensions of the IMI questionnaire: Interest/Enjoyment, Perceived Competence, Effort / Importance and Pressure/Tension. The first three variables have a positive correlation with values of $0.211(p=0.014), 0.200(p=0.02)$ and $0.198(p=0.021)$, respectively. In all cases a level of significance below 0.05 is obtained. This means that the greater the preference for reflective learning style by students in these three dimensions, the greater the intrinsic motivation. However, it also correlates negatively with regard to the Pressure / Tension dimension, with a value of $-0.200(\mathrm{p}=0.019)$. As in Table 1, this result was expected since the Pressure/Tension dimension is inverse to the other intrinsic motivation dimensions. In virtually all cases, a fairly high level of significance is maintained at 0.01 . The level of significance is 0.05 only in the perception of choice.

But the learning style that most correlates with the dimensions of the IMI questionnaire is Visual, specifically with the six and with a level of significance in virtually all cases of 0.01 . For the dimensions Interest/Enjoyment, Perceived Competition, Effort/Importance, Perceived Choice and Value/Usefulness, the positive correlation has values of $0.435(\mathrm{p}<0.001), 0.423(\mathrm{p}<0.001), 0.355(\mathrm{p}<0.001), 0.215$ $(\mathrm{p}=0.012)$ and $0.287(\mathrm{p}=0.001)$. In all these cases, when students show a greater preference for learning with a Visual style, they also have a greater intrinsic motivation towards the use of ICT. As in the previous case, it also correlates negatively with the Pressure / Tension dimension, with a value of $-0.269(\mathrm{p}=0.002)$, which confirms this trend.

Finally, it should be noted that two negative correlations are obtained between the Verbal learning style and the Interest/Enjoyment dimension with a value of -0.221 
$(\mathrm{p}=0.01)$, and between the Global learning style and the Effort/Importance dimension, with a value of $-0.202(\mathrm{p}=0.018)$. Therefore, in both cases a high value in the learning style implies a low value of the intrinsic motivation dimension or vice versa.

Additionally, other variables were taken into account when analysing the data. In the first place, the existence of differences according to the university at which the students have studied (Universidad de Castilla-La Mancha or Universidad Rey Juan Carlos) was analysed.

Taking into account the university, no significant difference was observed regarding student learning styles. Therefore, regardless of the institution at in which students' study, similar results are obtained.

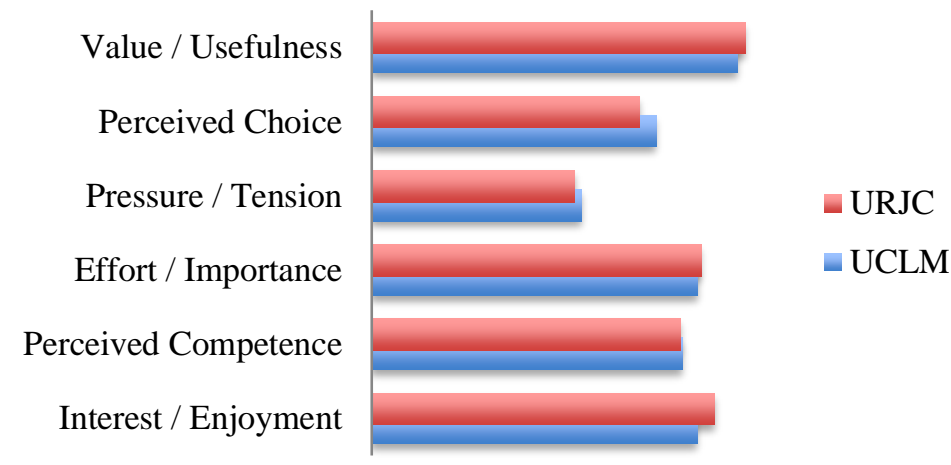

URJC = Universidad Rey Juan Carlos

UCLM = Universidad de Castilla-La Mancha

Fig. 2. Dimensions of motivation according to University

On the other hand, Figure 2 shows that there are some differences in the intrinsic motivation dimensions analysed. In general, equality predominates, with slight differences in half of them. Once the statistical analysis has been carried out to check if there are discrepancies among the means of the corresponding scores, only significant differences can be seen in the Choice perception of the IMI questionnaire, with a value of $t=2.066$ and $p=0.041$. The level of significance is 0.05 , which indicates that students of the Universidad de Castilla-La Mancha can be considered to have a greater Perceived Choice when using ICT.

However, if what is taken into account is students' gender, the differences observed in both questionnaires are greater. 


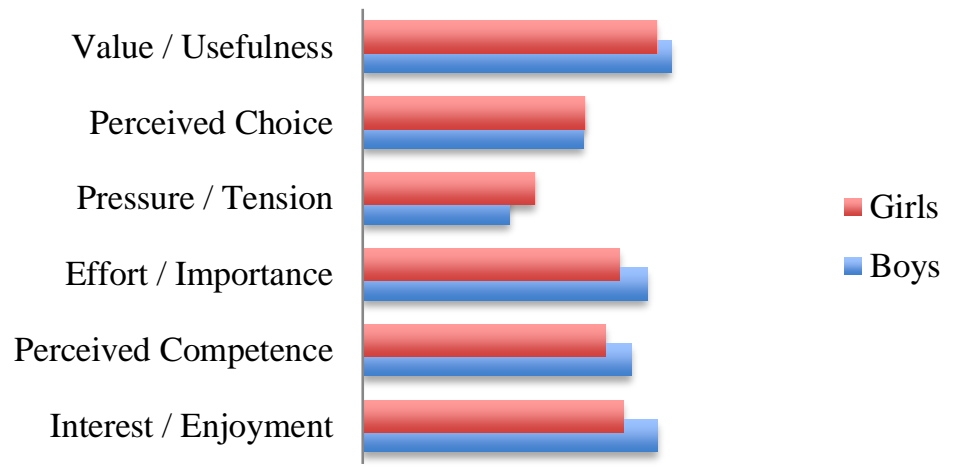

Fig. 3. Dimensions of motivation according to gender

Figure 3 shows the existence of differences in most cases. When performing the statistical analysis, there are no significant differences in the variables corresponding to Value/Usefulness and Perceived Choice. Therefore, the values of both genders are considered similar. However, in the other cases, when performing the contrast of means with Student's t, the opposite occurs. In three of the variables, Effort / Importance, Perceived Choice and Interest/Enjoyment, values of $t=3.252(p=0.002), 2.054$ $(p=0.046)$ and $2.883(p=0.006)$ are obtained, respectively. Furthermore, in all three cases boys' value is greater than girls', which indicates that they are more motivated in learning through ICTs.

Differences are also observed in the variable Pressure/Tension, where the value of Student's $t$ is equal to $-2.406(\mathrm{p}=0.020)$. Although girls obtain a greater value in this variable, since it is (as in the previous case) an inverse dimension, the motivation for learning through ICTs is greater in boys.

Finally, the differences found among the different learning styles of students based on gender were analysed.

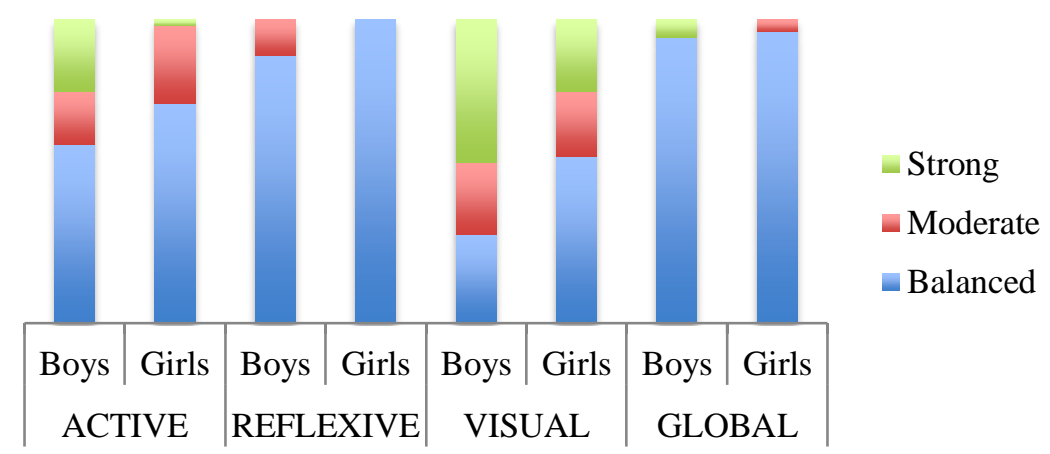

Fig. 4. Learning styles according to gender 
Figure 4 shows that the Active style is more present in boys, especially when the preference towards this modality is Strong. In this case, it has a value of 17.495 and an asymptotic (bilateral) significance of $<0.001$. That is, boys have an active learning style greater than girls, with a significance level of 0.01 .

A similar trend towards reflexive learning is also seen in Figure 4, as in the previous case. There is a greater presence of this style in boys, although only moderately. In girls, this learning style is totally non-existent. When performing the statistical analysis, a Chi-square value of 12.364 and an asymptotic (bilateral) significance of $<0.001$ are always obtained. As in the Active style, boys have a reflexive learning that is greater than girls', with a significance level of 0.01 .

Of the different styles that the Felder and Silverman Inventory analyses, there is one that is directly related to motivation towards the use of ICT, namely visual learning. As in the previous cases, in this one the boys have a greater tendency towards the Strong preference, with values that are almost in the middle. When performing the statistical analysis, a Chi-square value of 8.259 and an asymptotic (bilateral) significance of 0.016 are obtained. Hence, in the sample analysed, the male gender has a greater predisposition towards the style of Visual learning, with a level of significance of 0.05 .

Finally, the Global style is presented. In this case, it is also the boys who show a higher preference rate. When performing the statistical calculation, a Chi-square value of 7.344 and an asymptotic (bilateral) significance of 0.025 is obtained. There is a greater predisposition by the male sex towards learning with a Global style, with a significance level of 0.05 .

\section{$5 \quad$ Conclusion and Discussion}

The final part of this study consisted, on one hand, in contrasting the analysed data with the hypotheses formulated and, on the other, establishing the main conclusions obtained regarding the learning styles of the sample under examination and their preferences in relation to the learning style with which they identify most.

First, the relationships among the different variables of the two instruments used will be discussed. The dimensions of the IMI questionnaire have a high correlation, which implies that they all have a clear correspondence with each other. Therefore, it is possible to claim that the $\mathrm{H} 1$ hypothesis, which states that there is a correlation among the six subscales of the IMI questionnaire, is fulfilled, as proven in practically all the cases analysed. Regarding Felder and Silverman's inventory, it should be noted that there is no clear correlation among their eight learning styles. In some cases, this correspondence exists, but in many others it does not. Therefore, the $\mathrm{H} 2$ hypothesis, which states that there was a correlation among the participants' eight learning styles, must be partially accepted.

Regarding the relationship among the six dimensions of the IMI questionnaire and the eight learning styles of the Felder and Silverman Inventory, it should be noted that in most cases there is no clear relationship among these variables. However, there are two learning styles in which an evident correspondence is established with motivation, namely the Visual (totally) and the Reflective (in four of the six variables). 
Consequently, hypothesis $\mathrm{H} 3$ is partially accepted. The relationship among the variables that reflect a great motivation towards learning with ICT is important when preference is shown for a Visual style. In fact, the six intrinsic motivation variables correlate very strongly in virtually all cases. This fact is justified, given that for people who have a predisposition to perform learning visually are easily motivated by this form of accessing the educational process.

The H7 hypothesis, which claimed that differences existed among the participants' learning styles according to the home university variable, is rejected. Significant data have not appeared in any of the cases. However, when the home university is taken into account and related to the six dimensions of the intrinsic motivation inventory, some discrepancies are observed, although only one of them has statistically significant differences. Therefore, the H5 hypothesis is almost completely rejected as well and cannot be accepted.

On the other hand, the results are very different when the participants' gender variable is taken into account. In the different dimensions of motivation, discrepancies are seen in almost all cases. Therefore, the $\mathrm{H} 4$ hypothesis, which states that there are differences in the intrinsic motivation towards the use of ICT for participants based on gender, is accepted. Boys are more motivated towards learning, as opposed to girls. This is confirmed by four of the six variables, namely Effort/Importance, Perceived Competition, Interest/Enjoyment and Pressure/Tension.

There are also differences in learning styles where, in the case of children, preferences always appear towards a certain way of accessing knowledge. The H6 hypothesis, which stated that there are differences in the participants' learning styles according to gender, is partially accepted. This can be verified in four of the styles analysed, namely Active, Reflective, Global and Visual. The latter stands out for the clear relationship with the motivation for learning through ICT.

It is possible to conclude that some of these results could be expected, such as the clear correspondence between the dimensions of motivation and the negative correlations among learning styles that are opposites. In the other cases, there does not have to be any correspondence because each person has unique individual characteristics regarding his/her willingness to learn.

At present the use of ICTs in daily activities is very common. Bearing in mind that a significant number of students (mainly males) prefer using a Visual type of learning, there is a greater predisposition towards the use of technologies.

When the university in which students are enrolled is taken into account as a variable, no differences are found, and the samples must be considered to be similar even though the students live in different environments. However, clear differences are detected when participants' gender is considered, both in respect to motivation towards the use of ICTs and the preference expressed for a specific type of learning. Male students show greater motivation towards the use of technologies in learning. In addition, they show a greater preference for several learning styles in comparison with female students, including the Visual style, which is directly related with motivation in the use of ICTs. This correspondence between motivation towards learning through technologies and the Visual style corroborate the results foreseen at the beginning of the research study, given that this relationship is evident. 
Future research could focus on the application of these instruments to other different samples, such as students at risk of social exclusion with limited access to technologies. The use of another motivation questionnaire could also be considered, specifically one focusing on different variables to measure motivation towards the use of a specific device, such as a tablet or smartphone.

\section{$6 \quad$ References}

[1] Ryan, R.M., \& Stiller, J. (1991). The social contexts of internalization: Parent and teacher influences on autonomy, motivation and learning. In Advances in motivation and achievement (pp. 115-149). Greenwich: JAI Press.

[2] Ryan, R. M., \& Deci, E. L. (2000). Self-determination theory and the facilitation of intrinsic motivation, social development, and well-being. American Psychologist, 55(1), 68-78. https://doi.org/10.1037/0003-066X.55.1.68

[3] Ausubel, D. P. (1968). Educational psychology: A cognitive view. New York: Holt, Rinehart and Winston.

[4] García, F. J., \& Doménech, F. (1997). Motivación, aprendizaje y rendimiento escolar. Revista Electrónica de Motivación y Emoción, 1(0), 1-8.

[5] Elliott, E. S., \& Dweck, C. S. (1988). Goals: An approach to motivation and achievement. Journal of Personality and Social Psychology, 54(1), 5-12. https://doi.org/10.1037/0022-35 $\underline{14.54 .1 .5}$

[6] Vázquez, Á., \& Manassero, M. A. (2000). Análisis empírico de dos escalas de motivación escolar. REME, 3(5-6).

[7] Atkinson, J. W. (1976). An introduction to motivation. Van Nostrand: Princeton.

[8] Bandura, A. (1986). From thought to action: Mechanisms of personal agency. Journal of Psychology, 15, 1-17.

[9] Dweck, C. S., \& Leggett, E. L. (1988). A social cognitive approach to motivation and personality. Psychological Review, 95(2), 256-273. https://doi.org/10.1037/0033$\underline{295 X .95 .2 .256}$

[10] Hernández, A. (2017). Enseñar E/LE a la primera generación de nativos digitales. Foro de profesores de E/LE, (13), 165-176. https://doi.org/10.7203/foroele.13.10793

[11] Área, M., Cepeda, O., González, D., \& Sanabria, A. (2010). Un análisis de las actividades didácticas con TIC en aulas de educación secundaria. Un análisis de las actividades didácticas con TIC en aulas de educación secundaria, (38), 187-199. https://doi.org/10.22370/ieya.2017.3.2.714

[12] Aguaded, J. I., \& Tirado, R. (2010). Ordenadores en los pupitres: Informática y telemática en el proceso de enseñanza-aprendizaje en los centros TIC de Andalucía. Pixel-Bit. Revista de Medios y Educación, (36), 5-28. https://doi.org/10.26820/reciamuc/2.1.2018.505-516

[13] Deci, E. L., \& Ryan, R. M. (1985). Intrinsic motivation and self-determination in human behavior. New York: Plenum.

[14] Felder, R. M., \& Silverman, L. K. (1988). Learning and Teaching Styles in Engineering Education. Engineering Education, 78(7), 674-681.D

[15] Chekola, M. G. (1974). The concept of happiness. University of Michigan, Ann Arbor.

[16] Hull, C. L. (1925). An automatic correlation calculating machine. Journal of the American Statistical Association, 20, 522-531.

[17] Tolman, E. C. (1932). Purposive behavior in animals and men. New York: Appleton.

[18] Heider, F. (1958). The psychology of interpersonal relations. https://doi.org/10. $\underline{1037 / 10628-000}$ 
[19] Jones, E. E., \& Davis, K. E. (1965). From acts to dispositions: The attribution process in social psychology. In Advances in experimental social psychology (pp. 219-266). New York: Academic Press. https://doi.org/10.1016/s0065-2601(08)60107-0

[20] Kelley, H. H. (1967). Attribution theory in social psychology. In Nebraska Symposium on Motivation (Vol. 15, pp. 192-238). Lincoln: University of Nebraska Press.

[21] Weiner, B. (1985). An attributional theory of achievement motivation and emotion. Psychological Review, 92(4), 548-573. https://doi.org/10.1037/0033-295X.92.4.548

[22] Maslow, A. H. (1954). Motivation and personality. New York: Harper y Row Publishers Inc.D

[23] McClelland, D. C. (1958). Methods of measuring human motivation. In Motives in fantasy, action, and society (pp. 7-42). Princeton: D. Van Nostrand Company, Inc.D

[24] Deci, E. L., Vallerand, R. J., Pelletier, L. G., \& Ryan, R. M. (1991). Motivation and Education: The Self-Determination Perspective. Educational Psychologist, 26(3-4), 325-346.https://doi.org/10.1080/00461520.1991.9653137D https://doi.org/10.1207/s15326985ep2603\&4_6

[25] Deci, E. L. (1992). The relation of interest to the motivation of behavior: A self-determination theory perspective. In the Role of Interest in Learning and Development. Hillsdale:

Erlbaum.

[26] Pintrich, P. R., \& de Groot, E. V. (1990). Motivational and self-regulated learning components of classroom academic performance. Journal of Educational Psychology, 82(1), 33-40. https://doi.org/10.1037/0022-0663.82.1.33

[27] Grant, H., \& Dweck, C. S. (2003). Clarifying Achievement Goals and Their Impact. Journal of Personality and Social Psychology, 85(3), 541-553. https://doi.org/10.1037/0022-35 14.85.3.541

[28] McInerney, D. M., Marsh, H. W., \& Yeung, A. S. (2003). Toward a hierarchical goal theory model of school motivation. Journal of Applied Measurement, 4, 335-357.

[29] McAuley, E., Duncan, T., \&Tammen, V. V. (1987). Psychometric properties of the Intrinsic Motivation Inventory in a competitive sport setting: A confirmatory factor analysis. Research Quarterly for Exercise and Sport, 60, 48-58.F. https://doi.org/10.1080/02701367. 1989.10607413

[30] Eskeles, A. (1982). Relationships between academic intrinsic motivation and anxiety in children and young adolescents. Journal of School Psychology, 20(3), 205-215. https://doi. org/10.1016/0022-4405(82)90050-4

[31] Mendez, D., Mendez, M., \& Anguita, J. (2018). Motivation of 14-Year-old Students using Tablets, compared to those using Textbooks and Workbooks. International Journal of Interactive Mobile Technologies (iJIM), 12(4), 86. https://doi.org/10.3991/ijim.v12i4.9203

[32] Heilat, M. Q., \& Seifert, T. (2019). Mental motivation, intrinsic motivation and their relationship with emotional support sources among gifted and non-gifted Jordanian adolescents. Cogent Psychology, 6(1). https://doi.org/10.1080/23311908.2019.1587131

[33] Demir, K. (2011). Teachers' intrinsic and extrinsic motivation as predictors of student engagement. e-Journal of New World Sciences Academy, 6(2), 1397-1409.

[34] Liu, W., Li, X.-W., \& Zou, Y. (2019). The Formation of Teachers' Intrinsic Motivation in Professional Development. Integrative Psychological and Behavioral Science, 53(3), 418-430. https://doi.org/10.1007/s12124-018-9465-3

[35] Gardner, H. (2012). Inteligencias múltiples: La teoría en la práctica. Barcelona: Paidós Ibérica.

[36] Honey, P., \& Mumford, A. (2006). Learning styles questionnaire: 80-item version. London: Maidenhead. 
[37] Keefe, J. W. (1987). Learning style: Theory and practice. Reston, Va: National Association of Secondary School Principals.

[38] Honey, P., \& Mumford, A. (1986). Using your learning styles. Maidenhead, Angl.: Andingly House.

[39] Rose, C. (1985). Accelerated learning. Accelerated Learning Systems (2 ed). Cambridge: Topaz Publ.

[40] Herrmann, N. (1996). The whole brain business book. New York: McGraw-Hill.

[41] Gardner, H. (1983). Frames of mind: The theory of multiple intelligences. London UA: Heinemann.

[42] Kolb, D. (1976). Learning style inventory. Boston: McBer and Company.

[43] Alonso, C. M., Honey, P., \& Gallego, D. J. (1994). Los estilos de aprendizaje: Procedimientos de diagnóstico y mejora. Bilbao: Mensajero.F

[44] García, J. L., Santizo, J. A., \& Alonso, C. M. (2009). Instrumentos de medición de estilos de aprendizaje. Revista de Estilos de Aprendizaje, 4(4), 1-23. https://doi.org/10.37960/re vista.v24i2.31505

[45] Acosta, Y., \& Bernal, R. (2013). Estilos de aprendizaje y el trabajo en el aula. Revista Iberoamericana para la Investigación y el Desarrollo Educativo, 1-12. https://doi.org/10.23 913/ride.v3i5.65

[46] Lago, B., Colvin, L., \& Cacheiro, M. (2008). Estilos de Aprendizaje y actividades polifásicas: Modelo EAAP. Revista Estilos de Aprendizaje, 2(2).

[47] Navarro, O., Molina, A. I., Lacruz, M., \& Ortega, M. (2018). Utilización de los estilos de aprendizaje y el cociente intelectual para la constitución de dos grupos homogéneos. Revista De Estilos De Aprendizaje, 11(21). Retrieved of: http://revistaestilosdeapren dizaje.com/article/view/1091. https://doi.org/10.33064/25crscsh451

\section{$7 \quad$ Authors}

Oscar Navarro is PhD in Pedagogy by Universidad de Castilla-La Mancha (UCLM) and Bachelor in Pedagogy by the National University of Education at Distance. He has worked as a teacher in primary schools since 1997. He has also taught at the University Center of Studies of Talavera de la Reina and at the present time he is an Assistant Professor in the Department of Pedagogy of Castilla-La Mancha University. His main areas of interest are Inclusive Education, cultural diversity, the elaboration and implementation of multimedia materials with students of primary education, as well as the use of LMS systems and practices of e-learning. He pays especial attention on students with learning disabilities and social relationships between children in the early stages of education. I am part of the research groups "EDUCALIDAD" (UCLM), GRIOCE (UCLM) and "Calidad de Vida de las Personas con Discapacidad. Evaluación e intervención" at Camilo José Cela University.

Francisco Javier Sanchez-Verdejo holds a degree in English Philology and a PhD from the UCLM. He has more than 20 years of experience in teaching English. He is Professor at UCLM, in the Primary Education Degree, as well as at the UNED. Expert external examiner in Spanish National Agency SEPIE, he has also worked as the Plurilinguism Head of Unit at the Education Regional Ministry Government. In 2009 he received a scholarship -Job-Shadowing- for a stay at St. Joseph's College (Dublin). In 2014 he was appointed to participate in the European Workshop Pestalozzi program 
"Multilingualism for participation and social cohesion: quality and equity in European education" (Council of Europe). He is a teacher trainer in teaching and methodology His research interests cover bilingualism as well as bilingual education, social and cultural aspects when learning another language.

Juana Maria Anguita is $\mathrm{PhD}$ in Educational Sciences, MA in the Teaching of Spanish as Foreign Language and in Bilingual Education. Degrees in Translation and Interpreting, in English Studies and in Teaching. Expert in intercultural education, migratory movements, bilingualism, English-Spanish translation and the teaching of English as a foreign language. She has worked as a translator and language specialist for Lionbridge in Spain and for the International Baccalaureate in The Netherlands. She has also worked as a lecturer at Universidad Pablo de Olavide (Sevilla, Spain). At the present time she is a qualified Primary Education teacher in Madrid. In addition, she gives lectures in the Teaching Degree at Universidad Alfonso X El Sabio and at Universidad Rey Juan Carlos, and in the Master's Degree in Teacher Training at Centro Universitario Villanueva. She is part of the research group "Sociedad, Culturay Educación"at Universidad Camilo José Cela.

Angel Luis Gonzalez is $\mathrm{PhD}$ in Educational Sciences with an Extraordinary Doctorate Award from the Complutense University of Madrid, a degree in Pedagogy and Psychopedagogy and a Master in Psychotherapeutic Intervention from UNED. He is the Managing Director of the Almida Integration Group, Associate Professor of the Pedagogy Dept. of the University of Castilla-La Mancha, Professor of the Master in Educational Intervention in Social Contexts of the UNED and Associate Professor of the Faculty of Education of the Camilo University José Cela. His main lines of research are centered on the study of the orientation, training and employment of people with different abilities, professional guidance, educational guidance and tutorial advice. He is President of the National Confederation of Special Employment Centers (CONACEE), President of the Association of Companies of Social and Labor Integration of Persons with Disabilities of CLM (EINSO).

Article submitted 2020-03-23. Resubmitted 2020-04-28. Final acceptance 2020-04-30. Final version published as submitted by the authors. 